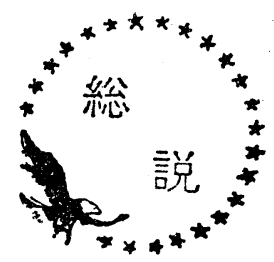

従来の石炭直接液化の研究と工業化

- 1971 年 8 月 20 日受理一

（石炭直接液化に関する講演会1976.4.5）

1. まえがき

高圧下に括ける石炭と水素との反応による石炭直接 液化は1913年の F.Bergius の特許にはじまる。工業 プロセスとして大成させたのは M.Pier 指導者とし た I.G.Farbenindustrie の技術陣であり，1931年に Leuna に特いて鉄系触媒を用い $250 \mathrm{~atm}$ の反応圧力 でかっ炭の工業的液化に成功した。痜青炭の工業的 液化を最初に行なったのは, I.C.I.の Bilingham 工 場である。しゅう酸すず＼cjkstart塩化アンモニウム触媒を用 い, 反応圧力は $300 \mathrm{~atm}$ であった。 I.G. は I.C.I. と同じ触媒, 同じ反応圧力での歷青炭の液化を 1936 年に Scholven で開始し，1939年には Gelsenbergに 扣いて 鉄系触媒, 反応圧力 $700 \mathrm{~atm}$ て瀝青炭の液 化に成功した。午の後 Poelitz, Wesseling の 2 工場 が建設されたが，いずれる鉄系触媒を用い反応圧力は $700 \mathrm{~atm}$ であった。

1945年, ドイッの敗戦とともに全工場の操業は禁止 され，その後東ドイッの Leuna のプラントの一部で 1959年 4 月までかっ炭の液化が続けられたが，この年 に原料が全面的に石油系重質油飞転換され，従来法に よる石炭の工業的液化に終止符がうたれた。他方, ア メリカ政府は戦後 I.G. のプロセスについて技術調 査を行ない，その結果をもとにして Bureau of Mines が1949〜1952年にデモンストレーション・プラントの 運転研究を行なった。また著者らは1956〜1961年にテ スト・プラントを用いて本邦炭の液化の研究を行なっ たが，これらはいずれも I.G. のプロセス，すなわ ち従来行なわれてきた使い捨て触媒汇よる石炭直接液 化の系列沙入る。

Bureau of Mines が 1950 年に刊行した “Bibliography of Pressure Hydrogenation” とはわが国に和 ける諸先輩の研究を含めて 2,500 編の石炭, タールな ぞの水素化分解に関する文献が収録されている。限ら れた紙数のうちに過去の膨大な研究成果を網らするこ とは困難なので, ここでは，そのうちの一部と工業化
公害資源研究所坂部孜

されたプロセスの概略について紹介し，併せて将来の 石炭液化プロセスについて私見を述べてみたい。

2. 石炭直接液化における反応諸条件と炭種の影響 （バッチ・オートクレーブによる実験結果）

2.1 時間, 温度和よび圧力

Bureau of Mines* の M.G.Pelipetz らの実験結 果苜図 1 〜図 3 亿示す。試料炭は Bruceton (C: $83.5 \%)$, 触媒は $\mathrm{SnS}(1 \%)+\mathrm{NH}_{4} \mathrm{Cl}(0.5 \%)$, 混 合油は石炭液化重油である。図1から明らかなように 石炭の分解率 (ベンゼン可溶物質への変換率) は比較 的早い時間で一定値に近ずき，時間の経過とともにア スファルト (ベンゼン可溶・石油エーテル不溶物質) が減少し, 油十水に変換されるが, 同時にガスの生成 が増大するので油の収量はある反応時間で最大とな る。図 2 から反応温度の上昇はアスファルトの分解に

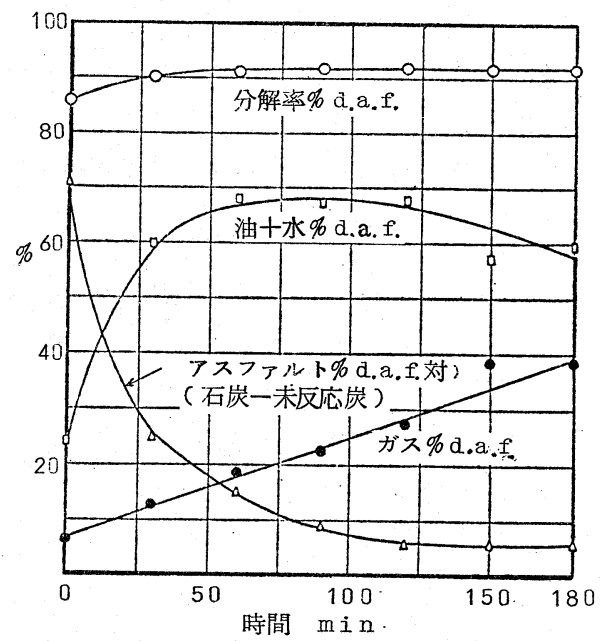

（水素初圧 $140 \mathrm{~kg} / \mathrm{cm}^{2}$, 反応温度 $450^{\circ} \mathrm{C}$ )

図 1 反応時間の影響

\footnotetext{
* 本章で Bur. Mines の実験結果を多く引用するの は, Bur. Mines が石炭液化の実験を開始した時期 が比較的和そく，そのため整理された結果が得られ ているからである。
} 


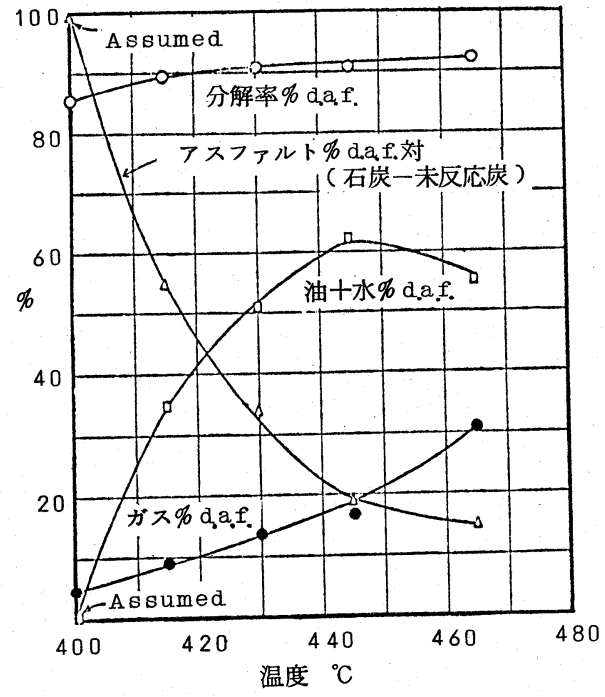

（水素初圧 $140 \mathrm{~kg} / \mathrm{cm}^{2}$, 反応時間 $1 \mathrm{hr}$ )

図 2 反応温度の影響

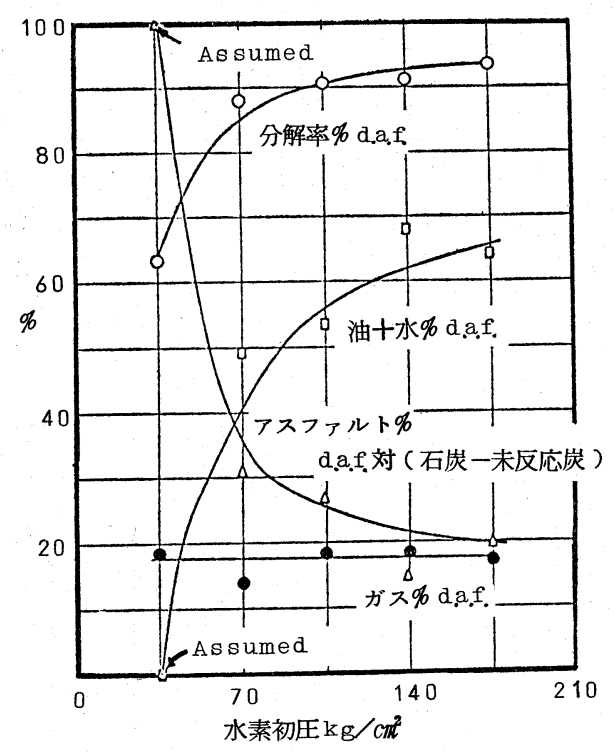

（反応温度 $450^{\circ} \mathrm{C}$, 反応時間 $1 \mathrm{hr}$ )

図 3 水素圧力の影響

著しい効果を示すが，他方，ガスの生成が增加するの で, 反応時間一定のとき, 油の収量はある反応温度で 最大となることがわかる。また図 3 に示したように， 反応圧力の增大は石炭分解率の向上, アスファルト分 解の促進，油の収量の増加などの好ましい結果をるた らし，かつガスの生成には影響を与兄ない。

S.Weller らは，このような石炭直接液化の反応
は，次のように進行し，石炭、アスファルトいずれの 分解も一次反応として, Bruceton の石炭を $\mathrm{SnS}$ (1 $\%)+\mathrm{NH}_{4} \mathrm{Cl}(0.5 \%)$ 触媒, 初圧 $175 \mathrm{~kg} / \mathrm{cm}^{2}$ で水 素化分解したときの反応速度定数を求めて表 1 の結果 を得ているっ2。

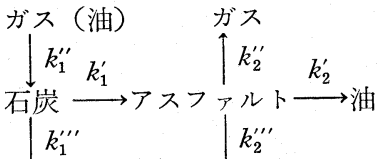

$$
\begin{aligned}
& \mathrm{H}_{2} \mathrm{O} \quad \mathrm{H}_{2} \mathrm{O} \\
& C=C_{0} e^{-k k_{1} t} \\
& A=\alpha C_{0} \frac{k_{1}}{k_{1}-k_{2}}\left(e^{-k_{2} t}-e^{-k_{2} t}\right) \\
& C \text { : 未反応炭量, } A: \text { アスファルト量 } \\
& C_{0} \text { : 当初の石炭量 (無水無灰) } \\
& k_{1}=k_{1}^{\prime}+k_{1}^{\prime \prime}+k_{1}^{\prime \prime \prime}, \quad k_{2}=k_{2}^{\prime}+k_{2}^{\prime \prime}+k_{2}^{\prime \prime \prime} \\
& \alpha=k_{1}^{\prime} / k_{1}
\end{aligned}
$$

\section{表 1 石炭水素化分解の反応速度定数}

\begin{tabular}{cccc}
\hline $\begin{array}{c}\text { 反応温度 } \\
\mathrm{C}\end{array}$ & $a$ & $\begin{array}{c}k_{1} \\
\mathrm{~min}^{-1}\end{array}$ & $\begin{array}{c}k_{2} \\
\mathrm{~min}^{-1}\end{array}$ \\
\hline 400 & 0.939 & 0.027 & 0.00107 \\
420 & 0.916 & 0.060 & 0.00503 \\
430 & 0.891 & 0.126 & 0.00895 \\
440 & 0.881 & 0.129 & 0.01282 \\
\hline
\end{tabular}

反応速度定数は石炭の種類, 触媒, 反応圧力, 混合 油の有無とその種類などによって值に影響を受ける が, 表 1 には石炭の大部分はアスファルトを経て油に 分解され, 石炭の分解速度にくらべてアスファルトの 分解速度がはるかに小さいといら反応の機構が示され ている。

2.2 触媒および混合油

石炭直接液化用の触媒については, きわめて膨大な 実験結果が報告されているが，ここには S. Weller ら の実験結果を表 2 亿示す 3 。 $\mathrm{Wy} .(\mathrm{C}: 78.0 \%)$, 水素初圧 $70 \mathrm{~kg} / \mathrm{cm}^{2}$, 反応温度 $450^{\circ} \mathrm{C}$, 反応時間 1 時間である。触媒の添加法は「粉 末」は粉末状の触媒を添加,「共粉研」は触媒を石炭 とともにボールミルで粉砕,「含浸」は触媒を水溶液 から石炭に含浸させるという3つの方法である。「粉 末」 $\mapsto$ 共粉确」 $\rightarrow$ 「含浸」の順に触媒は石炭とよく接触 し，かつ細かく分散されていることになり，いずれの 触媒についてみても実験結果は著しく改善される。触 媒の種類についてみると, アスファルトの分解に対す る効果に著しい差が見られる。 
表 2 触媒およびその添加法の影響

\begin{tabular}{|c|c|c|c|c|c|c|}
\hline \multirow{2}{*}{ 触媒 } & \multirow{2}{*}{ 添加法 } & \multirow{2}{*}{ 混合油 } & \multirow{2}{*}{$\begin{array}{l}\text { 分解率 } \\
\% \text { daf }\end{array}$} & \multicolumn{3}{|c|}{ 生 成 物 \% daf } \\
\hline & & & & アスファルト & 油 & HCガス \\
\hline \multirow[t]{2}{*}{ 無 触 媒 } & & & 33.4 & 2.8 & 10.4 & 9.0 \\
\hline & 粉 末 & & 38.9 & 6.9 & 8.1 & 13.1 \\
\hline \multirow[t]{2}{*}{$\mathrm{FeSO}_{4}(1 \% \mathrm{Fe})$} & 共粉挽 & & 66.2 & 24.1 & 21.2 & 11.4 \\
\hline & 含 浸 & & 84.9 & 38.9 & 21.7 & 15.0 \\
\hline \multirow{2}{*}{$\mathrm{FeSO}_{4}(0.5 \% \mathrm{Fe})$} & 含 浸 & & 85.0 & 42.8 & 19.8 & 13.0 \\
\hline & 粉 末 & & 44.2 & 6.8 & 13.2 & 13.4 \\
\hline \multirow[t]{2}{*}{$\mathrm{NiCl}_{2}(1 \% \mathrm{Ni})$} & 共粉砕 & & 56.9 & 17.2 & 19.3 & 10.4 \\
\hline & 含 浸 & & 88.3 & 15.5 & 45.3 & 18.0 \\
\hline $\mathrm{NiCl}_{2}(0.5 \% \mathrm{Ni})$ & 含 浸 & & 81.7 & 36.8 & 21.7 & 14.0 \\
\hline \multirow{2}{*}{$\mathrm{SnCl}_{2}(1 \% \mathrm{Sn})$} & $\{$ 粉 末 & & 82.3 & 26.5 & 29.2 & 14.5 \\
\hline & ，含 浸 & & 88.3 & 19.9 & 41.4 & 15.5 \\
\hline \multirow{2}{*}{$\mathrm{SnCl}_{2}(0.5 \% \mathrm{Sn})$} & $\{$ 粉 末 & & 67.9 & 23.4 & 20.0 & 13.4 \\
\hline & \{含 浸 & & 86.3 & 37.3 & 28.0 & 11.2 \\
\hline \multirow{2}{*}{$\begin{array}{r}\left(\mathrm{NH}_{4}\right)_{6} \mathrm{Moo}_{2} \mathrm{O}_{24} \\
\quad(1 \% \mathrm{Mo})\end{array}$} & $\{$ 粉 末 & & 33.7 & 1.0 & 13.8 & 8.1 \\
\hline & 含 浸 & & 92.7 & 27.2 & 41.1 & 13.6 \\
\hline 無 触 媒 & & 石炭液 & 64.9 & 47.0 & -4.6 & 10.4 \\
\hline \multirow{2}{*}{$\begin{array}{r}\left(\mathrm{NH}_{4}\right)_{6} \mathrm{Mo}_{7} \mathrm{O}_{24} \\
(1 \% \mathrm{Mo})\end{array}$} & $\{$ 粉 末 & 化重油 & 82.2 & 76.8 & -17.7 & 12.7 \\
\hline & \{含 浸 & $1: 1$ & 93.0 & 40.4 & 31.8 & 9.4 \\
\hline
\end{tabular}

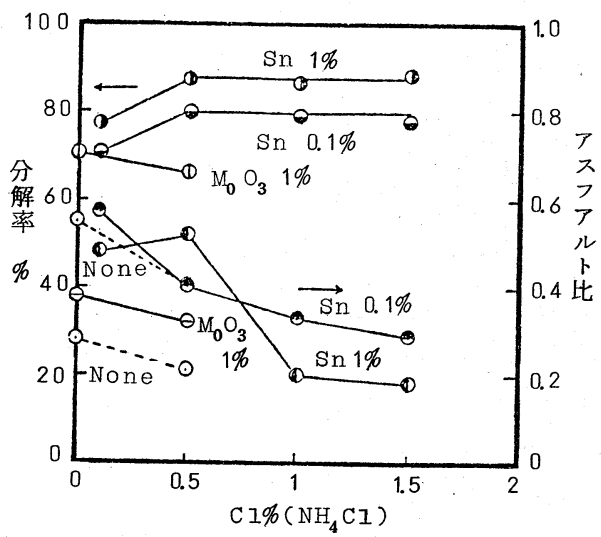

図 4 塩化アンモニウム添加の効果

図 4 には, 塩化アンモニウム添加の効果を示し た 。試料炭は Bruceton, 水素初圧 $70 \mathrm{~kg} / \mathrm{cm}^{2}$, 反応 温度 $450^{\circ} \mathrm{C}$, 反応時間 1 時間である。アスファルト比 は分解した石炭に対する生成アスファルトの比を示 す。塩化アンモニウムの添加は $\mathrm{Sn}$ 预よび $\mathrm{Zn}$ 触媒 の場合に効果を現わす。前述のように工業的にはしゅ ら酸スズ+塩化アンモニウムが用いられたが，ドイッ に拉いては一工場のみにとどまり，その後鉄触媒，反 応圧力 $700 \mathrm{~atm}$ が採用されたことからみても，塩化 物の使用には腐蝕などの点で問題があったと考兑るべ
きであろら。

表 2 飞る混合油の効果が示されているが, 石炭の溶 剂抽出扔よび水素化分解に対する混合油の化学構造の 影響を示す実験結果を表 3 に示した ceton, 溶剤抽出の場合は石炭 : 混合油 $=1: 4$, 抽出温 度 $400^{\circ} \mathrm{C}$, 水素化分解の場合は石炭: 混合油=1:1, 触媒は $\mathrm{SnS}(1 \%)+\mathrm{NH}_{4} \mathrm{Cl}(0.5 \%)$, 水素初圧 $70 \mathrm{~kg} /$ $\mathrm{cm}^{2}$, 反応温度 $400^{\circ} \mathrm{C}$ である。いずれの場合もアロ マチックな化合物よりはハイドロアロマチックな化合 物が, また炭化水素よりは水酸基をるった化合物が混 合油として優れていることを示している。

\section{3 炭種}

一般的にいって, 液化されやすい石炭は, 炭素含有 量が少なく, 水素含有量, 揮発分, 乾留したときの夕 一ル収量, 溶剤抽出量, 硫黄分が多く, かつ灰分中に 鉄などの触媒効果を有する元素が多く、アルカリ性成 分の少ない石炭とされている。

M. Sudzilovskaya らの実験によると石炭 の水素： 炭素原子比と水素化分解の際の分解率和よび生成油収 率の関係は図 5 叔よび図 6 のようになり, 反応圧力が 250〜280 atm の場合は 650 700 atm の場合にくら べ炭種の影響が顕著に 現われる ${ }^{6)}$ 。 $\mathrm{H} / \mathrm{C}=0.98$ の点 はから炭であり, 酸素含有量が多いため生成油収率は 
表 3 混 合 油 の 影響

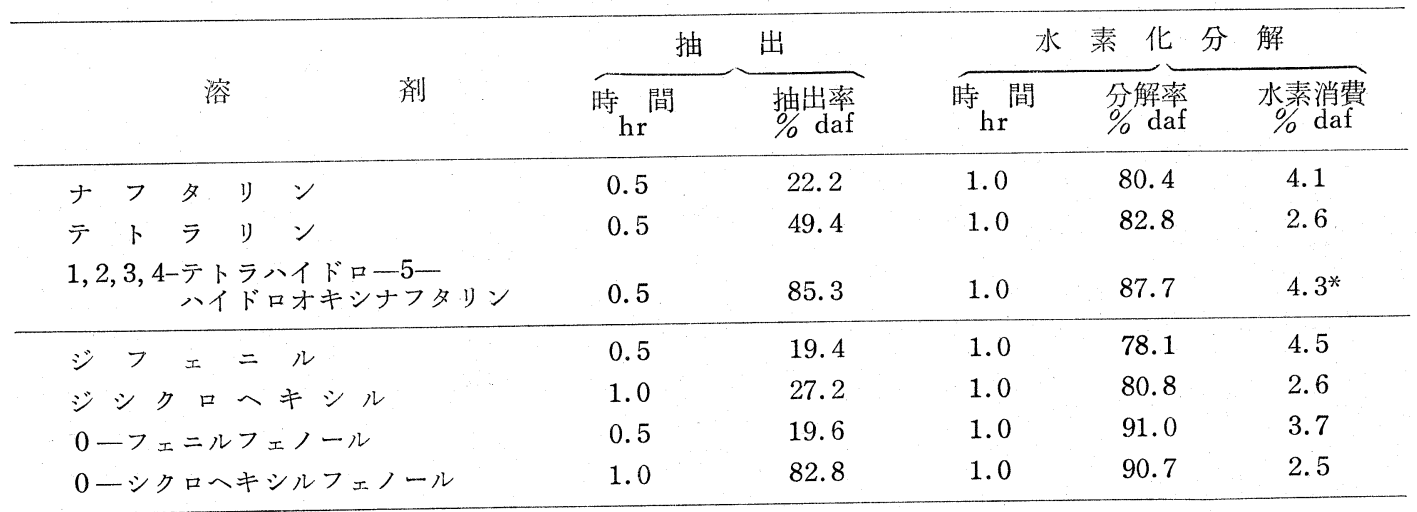

* $\mathrm{CH}_{4} 7.3 \%$ daf が生成

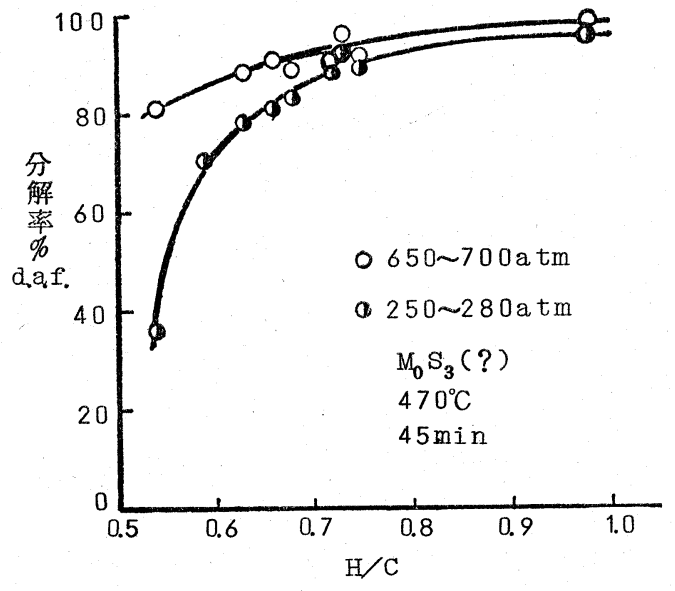

図 5 原料炭の $\mathrm{H} / \mathrm{C}$ と分解率の関係

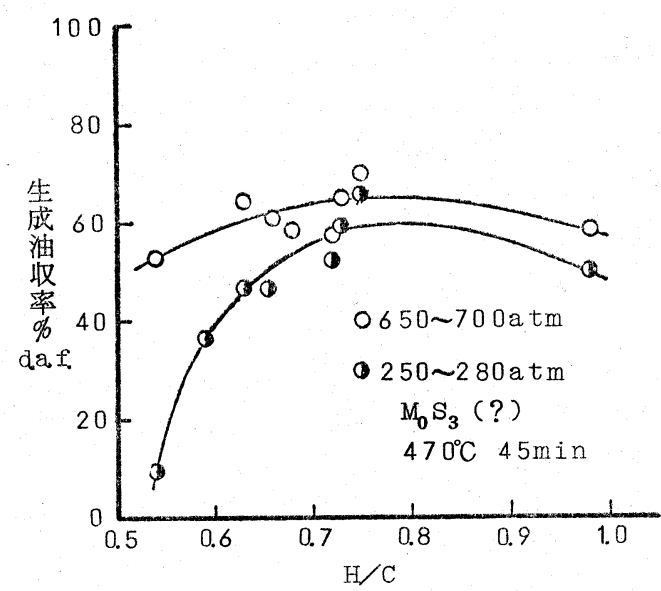

图 6 原料炭の $\mathrm{H} / \mathrm{C}$ と生成油収率の関係

低下している。

な特，C.H.Fischer らによると石炭水素化分解の

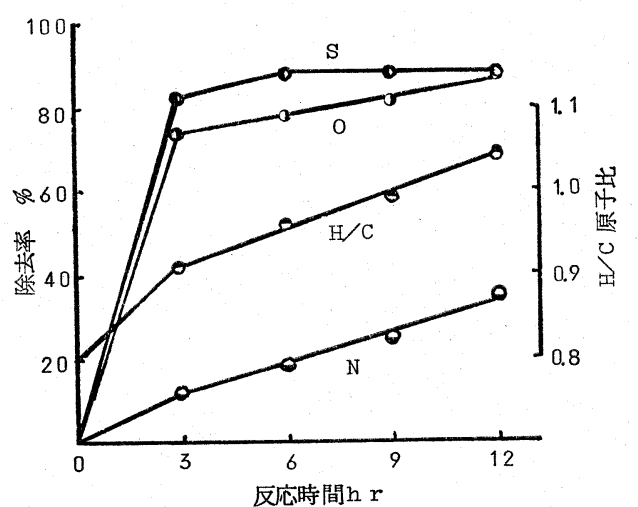

図 7 石炭水素化分解の過程における $\mathrm{O}, \mathrm{N}, \mathrm{S}$ の除去率と $\mathrm{H} / \mathrm{C}$ の変化

過程に频ける $\mathrm{O}, \mathrm{N}, \mathrm{S}$ の除去率と $\mathrm{H} / \mathrm{C}$ の変化は図 7 のようになる7。試料炭は Bruceton, 触媒は $\mathrm{SnS} 1$ $\%$, 混合油はテトラリン, 水素初圧 $70 \mathrm{~atm}$, 反応温 度 $415^{\circ} \mathrm{C}$ である。

\section{3. 石炭直接液化の連続化および工業化}

石炭直接液化は石炭からのガソリン製造法として工 業化された。石炭は, まず第 1 段の液相水素化分解の 反応工程で常圧蒸留で留出可能な留分に変換され, つ いでこの留出油は気相で氷素化処理されてガソリンが 製造された。気相水素化工程は, 反応圧力 $250 \sim 300$ atm のプラントでは水素化精製と水素化分解の組合 せ, 反応圧力 $700 \mathrm{~atm}$ のプラントでは 1 段の水素化 分解であった。

\section{1 石炭の液相水素化分解}

\subsection{1 フローシートと運転条件}

簡略化したフローシートを図 8 に示した。

原料炭は触媒とともに粉砕, 乾燥したのち重質油と 混合されて石炭ペーストが調製され，ポンプアップさ 


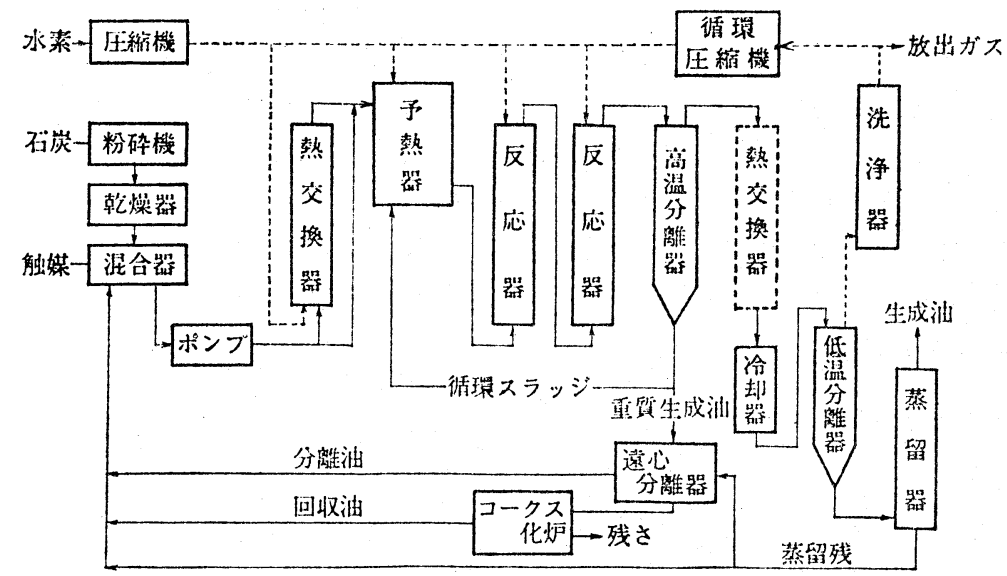

図 8 石炭液相水素化分解のフローシート

表 4 原料炭の組成 と運転条件

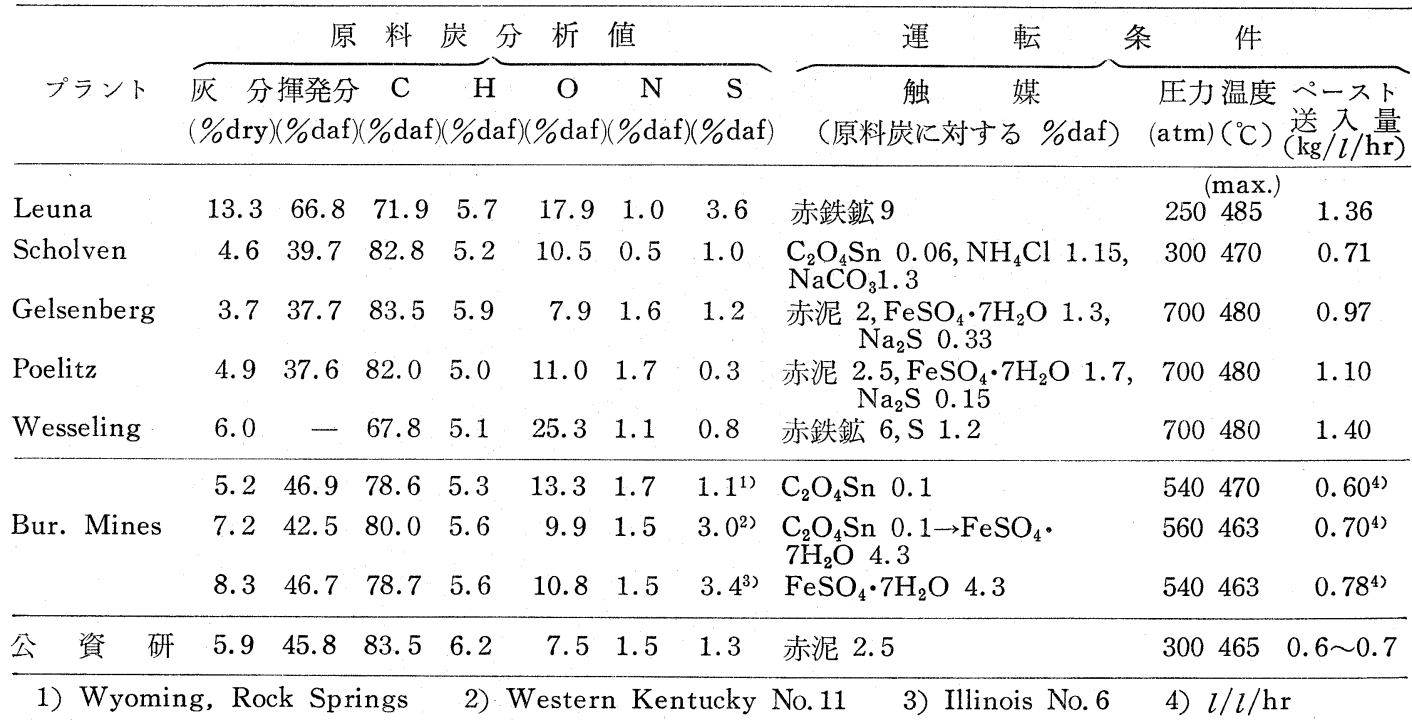

れたのち, 熱交撸器と子熱器を経て $425^{\circ} \mathrm{C}$ に加熱され て反応器炕入る。ドイッの工業装置 ${ }^{8)}$, Bureau Mines のデモンストレーション・プラント9执よび著者らの 用いたテストプラント ${ }^{10)}$ の原料炭と運転条件の関係を 表4 に示した。表4 の原料炭を $\mathrm{H} / \mathrm{C}-\mathrm{O} / \mathrm{C}$ （原子 比）ダイヤグラムにプロットすると図 9 のようにな る $^{11)}$ 。

著者らが原料炭として用いた三池炭拈よび Leuna で原料炭として用いられたかっ炭は，D.W. Van Krevelen による平均線 ${ }^{12)}$ とくらべてもっとも H/C が大きく，鉄系触媒を用いて 250 300 atm で水素化 分解が可能であった。これらの原料炭についで上部に
位置する瀝青炭は Gelsenberg の原料炭である。 また Wesseling で用いられたかっ炭の H/C は平均 線に近く, いずれも鉄系触媒を用いて $700 \mathrm{~atm} て ゙$ 水 素化分解され，高い分解率（96～97\% 拉よび 99\%) が得られている。平均線上に位置する瀝青炭を原料 炭として用いた Scholven 抢よび Poelitzの場合は しゅう酸すず+㷪化アンモニウム触媒を用いて 300 atm 和よび鉄系触媒を用いて $700 \mathrm{~atm}$ で水素化分解 されたが，いずれの場合も分解率は 92〜94\% と低い 值を示した。このように $\mathrm{H} / \mathrm{C}-\mathrm{O} / \mathrm{C}$ ダイヤグラムは 石炭の水素化分解適性の判断に役立てることができ る。 


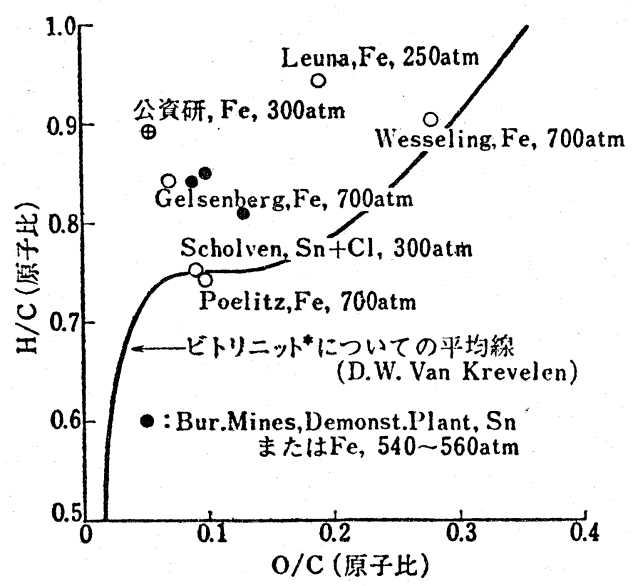

*ビトリニットは石炭の顕微鏡観察の際に輝きが強く見え る微細組織成分. 灰分が少なく，一般的には輝きの鈍い 組瀻成分 (ドリット) に比べて液化されやすい。

図 9 液化原料炭の $\mathrm{H} / \mathrm{C}-\mathrm{O} / \mathrm{C}$ ダイヤグラムへ のプロット

反応器を出た生成物はすず高温分離器へ送られ，未 反応炭，灰分，触媒などの固形分を含む重質油が分離 されて抜き出され, 遠心分離によって固形分が分離さ れ, これはさらにコーカーにかけられる。ドイッのプ ラントに怙ける高温分離器温度は $445 \sim 450^{\circ} \mathrm{C}$ であっ た。高温分離器のオーバーフローは熱交換器, 冷却器 を経て低温分離器へ送られ, 油分とガスが分離され る。油分は抜さ出されたのち常圧蒸留によって目的と する生成油が留出され, 残油はペースト製造工程にも どされる。ガスは洗浄されたのち循環使用され, 水素 濃度を一定（約 $80 \%$ ）に保つため一部が放出される。

\section{1 .2 ヒート・バランス}

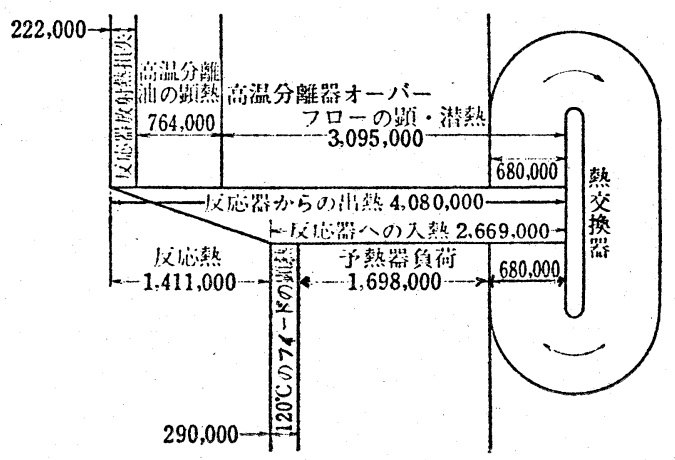

壆集温度： $52^{\circ} \mathrm{C}$, 単位: $\mathrm{kcal} / \mathrm{hr}$

ペースト送入量: $9,155 \mathrm{~kg} / \mathrm{hr}$ 。水絜送入量 $: 1,720 \mathrm{~kg} / \mathrm{hr}$

図 10 液相水素化分解工程のヒート・バランス
石炭の液相水素化分解は発熱反応であり, 常圧留出 油を目的とする場合, 反応熱は Ruhr の歴青炭で は水素を $1.85 \mathrm{~m}^{3} / \mathrm{kg}$ 生成油消費して $650 \mathrm{kcal} / \mathrm{kg}$ 生成油, Leuna のかっ炭では水素を $1.45 \mathrm{~m}^{3} / \mathrm{kg}$ 生成油消費して $550 \mathrm{kcal} / \mathrm{kg}$ 生成油であっだ)。 $\mathrm{Bu}$ reau of Mines のデモンストレーション・プラント のヒート・バランスを示すと図10のようになる ${ }^{13)}$ 。

デモンストレーション・プラントは, 最大限に熱回 収するように設計されて执らず, 高温分離器オーバー フローの顕・潜熱の $22 \%$ が利用されているにすぎな いが，適切な熱交換の方式を採用すればフィードの75 \%は予熱器なしで反応開始温度まで加熱することが できるといわれている。ただし，瀝青炭を原料とす るときは, 図11に示したように, 石炭粒子の膨潤によ って $300^{\circ} \mathrm{C}$ 前後に高粘度の領域が生じ, 石炭ペースト の輸送性が著しく損われるので，その対策が必要とな る8)。一つの方法としてドイッのプラントでは石炭ぺ ーストを希薄ペーストと濃厚ペーストの 2 種類とし, 高粘度領域以下に加熱した濃厚ペーストと十分高温に 加熱した希薄ペーストを混合することによって，急激 に高粘度領域をこえさせる方法がとられた。

また反応熱との関係で問題となるのは反応器の温度 コントロールである。反応熱による過度の温度上昇 を防ぐため高圧の冷水素でクェンチを行ならが，他方 反応器内に持将る過度の蒸発を防いで反応器をいつ流 型に保つため水素 : ペースト比は $2.3 \mathrm{Nm}^{3} / \mathrm{kg}$ 以下と することが要求される。反応器内容積 $2.5 \mathrm{~m}^{3}$ の $\mathrm{Bu}-$ reau of Mines のデモンストレーション・プラント では水素の $38 \%$ が, 反応器内容積 $10 \mathrm{~m}^{3}$ のドイッ の工業プラントでは水素の $55 \%$ が冷却用に用いられ た。将来の石炭液化には $100 \mathrm{~m}^{3}$ 級の反応器が用いら れることになると思われるが，温度コントロールには 新しい工夫が必要となり, 場合によっては反応の進行

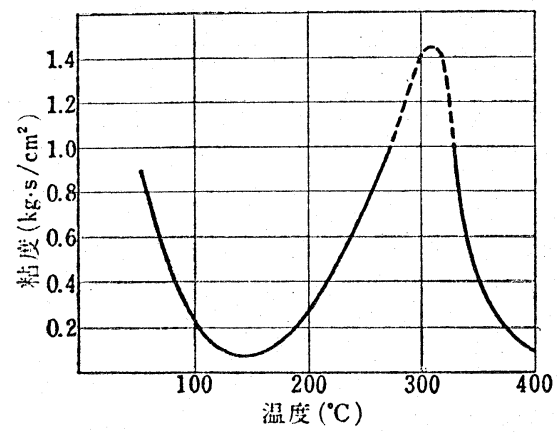

図 11 歴青炭ペーストの粘度と温度の関係 


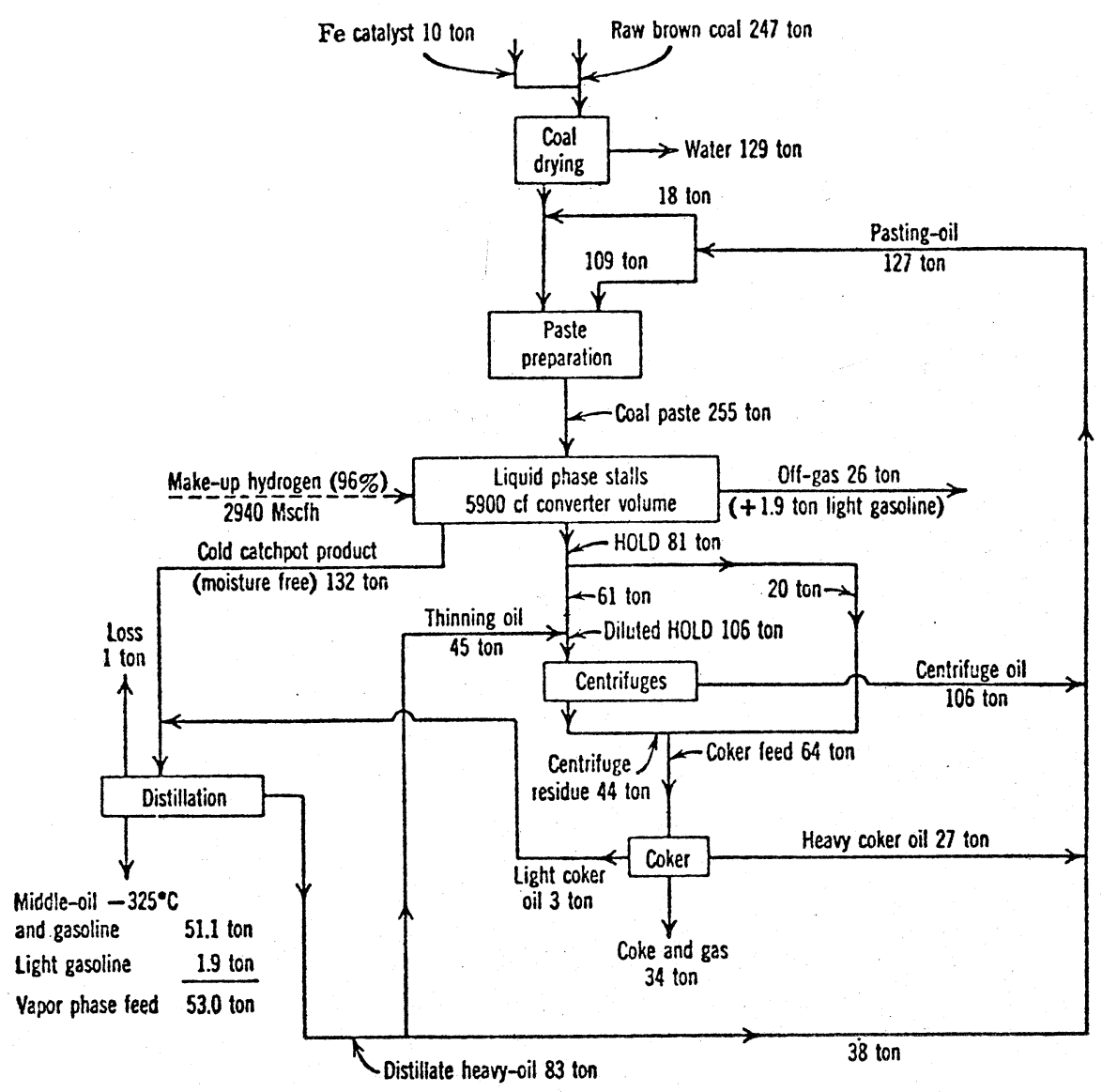

図 12 かっ炭液化のマテリアル・バランス（無水無灰炭 $100 \mathrm{t}$ 当たり）

をある程度扣さえざるを得なくなることも予想され る。

\section{1 .3 マテリアル・バランス}

ドイッに拈ける反応圧力 $250 \mathrm{~atm}$ のかっ炭液相水 素化分解怙よび反応圧力 $700 \mathrm{~atm}$ の瀝青炭液相水素 化分解のマテリアル・バランスを図12拉よび図13に示

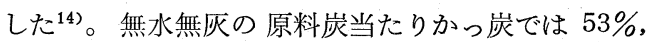
瀝青炭では $61.3 \%$ の常圧留出油が得られている。

図12蛙よび図13を見ると重質生成油から遠心分離に よって未反応炭, 灰分, 触媒などの固形分を分離する 工程のロードがきわめて大きいことがわかる。固形分 分離の難易は固形分拈よびアスファルトの含有量に支 配される。アスファルトについてはドイッのプラント では次の基準が設けられていた。

（1）ペースト油として循環される重質油中のアスフ アルトは $10 \%$ を越えてはならない。

(2) コーカー（ボールファーネス）に入る生成物の アスファルト/固形分は $1 / 3$ を越えてはならない。
表 4 の運転条件は，この基準を満足させるよう選ば れたものである。

\section{1 .4 生成油の組成}

著者らのテスト・プラントによる三池炭の液化生成 油の組成と中性油留分の構造グループ分析の結果を表 5 特よび表 6 亿示した ${ }^{15)}$ 。

生成油中には約 $15 \%$ のフェノール類が含まれてお

表 5 三池炭液化生成油（常圧留出油）の組成

\begin{tabular}{|c|c|c|c|c|}
\hline \multirow[t]{6}{*}{ 酸 } & 性 & 油 & $\%$ & 14.8 \\
\hline & \multicolumn{3}{|c|}{ 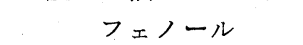 } & 25.2 \\
\hline & \multicolumn{3}{|c|}{0 ークレゾール } & 10.3 \\
\hline & \multicolumn{3}{|c|}{$\mathrm{m}$ ークレゾール } & 25.4 \\
\hline & \multicolumn{3}{|c|}{$\mathrm{P}$ 一クレゾール } & 8.2 \\
\hline & \multicolumn{3}{|c|}{ 小 計 } & 69.1 \\
\hline 塩 & 基 性 & 油 & $\%$ & 5.3 \\
\hline 中 & 性 & 油 & $\%$ & 76.6 \\
\hline 硫 & 黄 & 分 & $\%$ & 0.10 \\
\hline
\end{tabular}




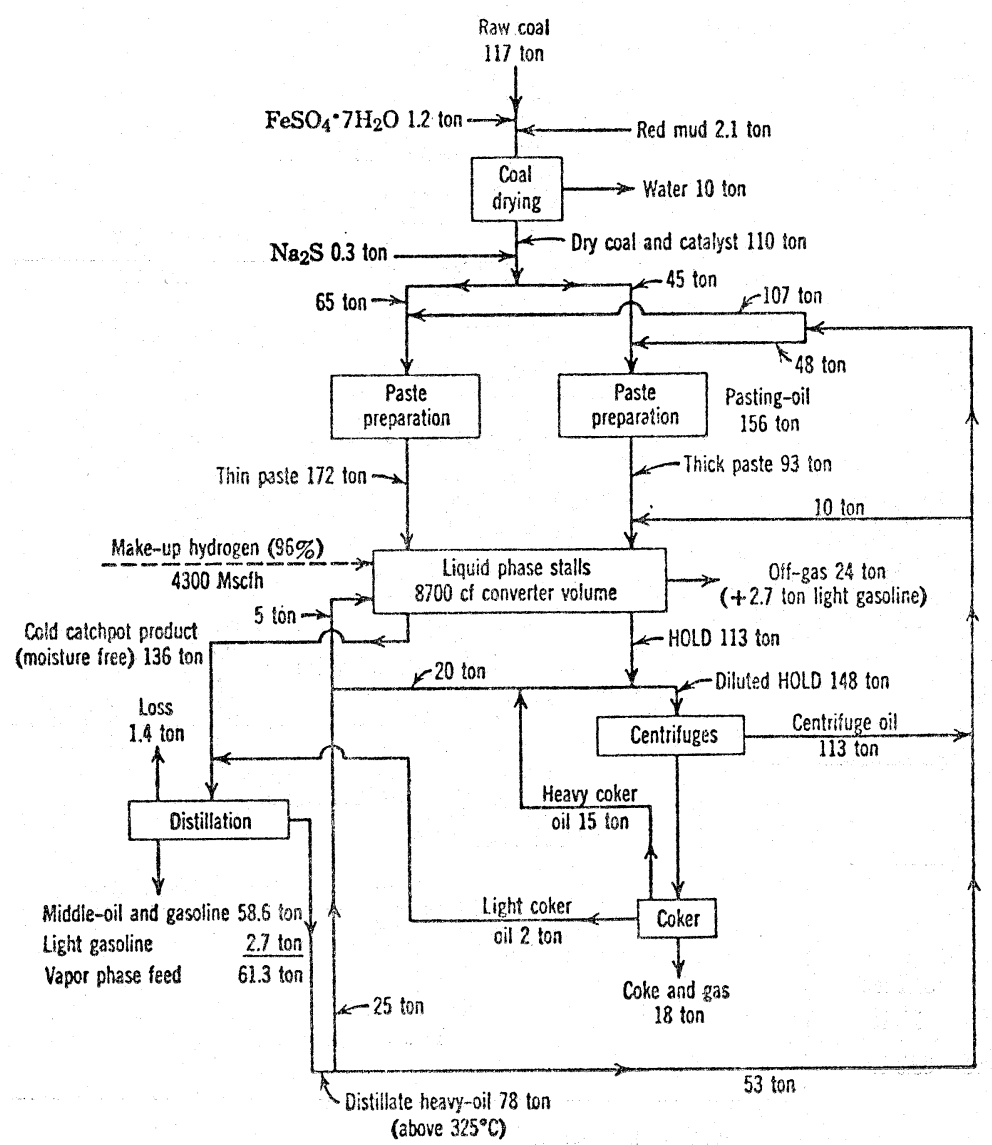

図 13 歴青炭液化のマテリアル・バランス（無水無灰炭 $100 \mathrm{t}$ 当たり）

表 6 三池炭液化生成油中性油留分の構造グループ分析

\begin{tabular}{rcccccc}
\hline $\begin{array}{c}\text { 留出温度 } \\
{ }^{C} \mathrm{C}\end{array}$ & $\begin{array}{c}\text { 留出量 } \\
\mathrm{wt} \%\end{array}$ & $\begin{array}{c}\mathrm{C}_{\mathrm{R}} \\
\%\end{array}$ & $\begin{array}{c}\mathrm{C}_{\mathrm{A}} \\
\%\end{array}$ & $\begin{array}{c}\mathrm{C}_{\mathrm{P}} \\
\%\end{array}$ & $\mathrm{R}_{\mathrm{T}}$ & $\mathrm{R}_{\mathrm{A}}$ \\
\hline 200 & 16.4 & 66.4 & 24.4 & 33.6 & 1.07 & 0.38 \\
$200 \sim 250$ & 24.1 & 74.8 & 39.9 & 25.2 & 1.70 & 0.79 \\
$250 \sim 280$ & 19.1 & 72.6 & 43.2 & 27.4 & 1.95 & 1.00 \\
$280 \sim 310$ & 21.0 & 75.7 & 51.4 & 24.3 & 2.25 & 1.29 \\
\hline
\end{tabular}

$\mathrm{C}_{\mathrm{R}}$ : 環状炭素, $\mathrm{C}_{\mathrm{A}}$ : 芳香族炭素, $\mathrm{C}_{\mathrm{P}}$ : 鎖状炭素, $\mathrm{R}_{\mathrm{T}}$ : 分子中の全環状構造の数, $\mathrm{R}_{\mathrm{A}}$ : 分子中の芳香族環の数

りこれを分離して製品化するといら考方方もあった が，不純物を含むため酸化されて着色しやすいといら 欠点がある。中性油留分は石炭化学構造の芳香族性の ため通常の原油から得られる同一留分に比較すると環 状構造に富み，芳香族含有量も多い。したがって中間 留分を灯油または軽油に代替する場合は煙点またはセ タン価が問題となる。

\section{2 石炭液化生成油の気相水素化処理}

石炭の液相水素化分解工程で得られた常圧留出油は
反応圧力 250 ３00 atm のプラントでは水素化精製と 水素化分解の組合せにより, た反応生力 $700 \mathrm{~atm}$ のプラントでは 1 段の水素化分解でガソリンに変換さ れた。反応条件を表 7 に示した ${ }^{14)}$ 。1 段水素化分解の 運転例によると, 石炭液化による常圧留出油をリサイ クル比 0.71 対バージンフィード, 液空間速度 1.09 $\mathrm{kg} / l$ 触媒 $/ \mathrm{hr}$ で水素化分解してガソリン $1.07 l / l$, ガス $\left(\sim \mathrm{C}_{4}\right) 9.4 \%$ が得られ, この場合の水素消費 は $4.7 \%$ である ${ }^{9}$ 。 
表 7 気相水素化処理工程の反応条件

\begin{tabular}{|c|c|c|c|c|}
\hline \multirow{2}{*}{$\frac{\text { 圧 }}{\text { 工 }}$} & \multirow{2}{*}{$\begin{array}{l}\text { 力 } \\
\text { 程 }\end{array}$} & \multicolumn{2}{|c|}{$250 \sim 300$ atm } & \multirow{2}{*}{$\begin{array}{c}700 \mathrm{~atm} \\
\text { 水素化分解 }\end{array}$} \\
\hline & & 予備 水素化 & 水素化分解 & \\
\hline 触 & 媒 & $\begin{array}{l}\mathrm{WS}_{2} \\
\mathrm{WS}_{2} \cdot \mathrm{NiS} \text { ア }\end{array}$ & $\mathrm{WS}_{2} \cdot \mathrm{HF}$ 処理活性白土 & $\mathrm{CrZnMoS} \cdot \mathrm{HF}$ 処理活性白土 \\
\hline 温 & 度 & $330^{\circ} \mathrm{C}$ & $400^{\circ} \mathrm{C}$ & $480^{\circ} \mathrm{C}$ \\
\hline
\end{tabular}

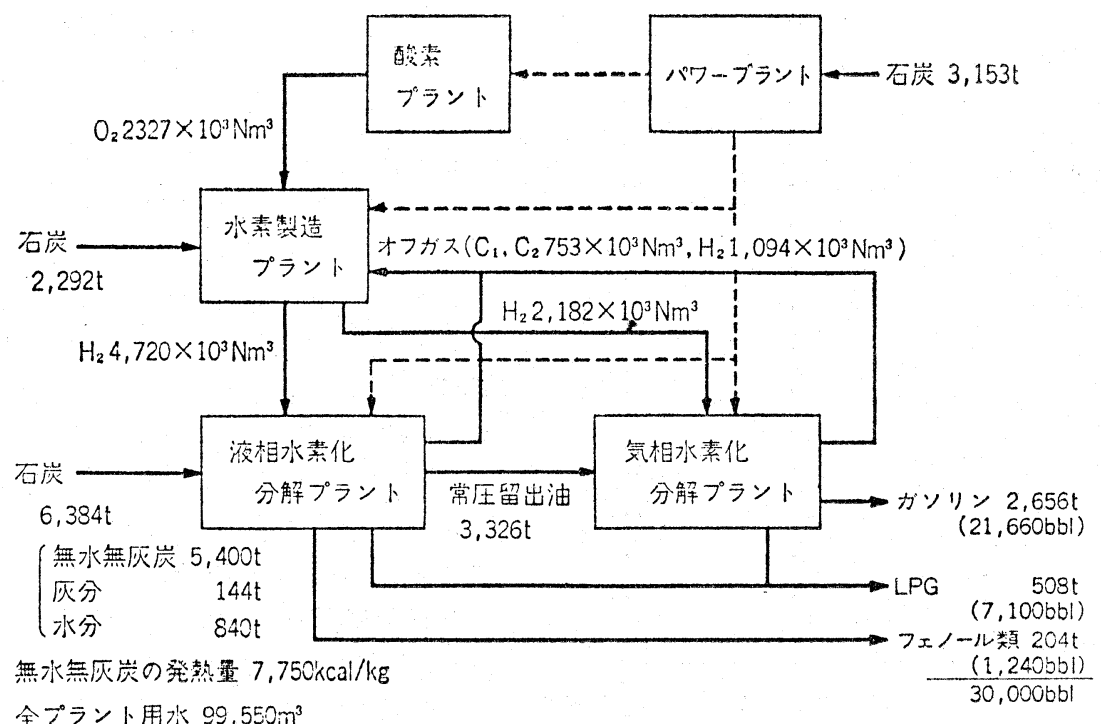

図 $1430,000 \mathrm{bbl} / \mathrm{d}$ 計画のマテリアル・バランス

(水素製造用ならび動力用の石炭は水素化分解原料用と同じである。)

Rock Springs 炭の 2 段水素化分解生成 ガソリン 扎よびそのハイドフォーメートの組成を表 8 亿示し た。

\section{3 ガソリン製造のエネルギー効率}

液化原料炭の発熱量に対する製品の発熱量は, 歴 青炭を原料としたドイッのプラントに拉いては, ガソ リンのみで $66.5 \%$ ，副産される燃料ガスを含めると 83.5\% であったが，水素製造拈よびパワープラント で用いられた石炭を加壳た全入熱に対してはガソリン のみでは $21.6 \%$, 然料ガスを含めても $27.2 \%$ と低い 值であっだす。の最大の原因は水性ガス発生炉の熱 損失が，全入熱に対して $35.5 \%$ と大きかったことに あった。Bureau of Mines では1949年に反応圧力700 atm の 2 段水素化分解によってガソリン, LPG, フ ェノール類を合計 $30,000 \mathrm{bbl} / \mathrm{d}$ 生産する場合につい てフィージビリティー・スタディを行なった ${ }^{16)}$ 。水素 源としては水素化分解工程で生成する $\mathrm{C}_{1} \sim \mathrm{C}_{2}$ 炭化水 素の水蒸気改質と原料炭の完全がス化が考兄られた。
要約したマテリアル・バランスを図14に示したが，こ の場合のエネルギー効率はガソリン+LPG で $46 \%$ と なる。

\section{4.むすび}

以上に従来の石炭直接液化の研究と工業化の概略を 述べた。著者は先に瀝青炭 (夕張炭) の化学的構造 について研究し, 瀝青炭の基本構造単位は平均的に は縮合 3 環の芳香核を有することを明らかにした その後の研究を見ても，この結論を大幅に変えるよう な知見は得られていないように思われる。縮合 3 環の 芳香核の水素化分解は次のよらに行なわれる。

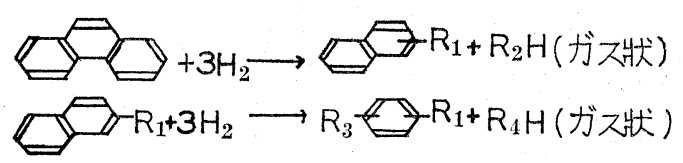

したがって石炭を表 8 に組成を示したよらな単環の 炭化水素を主成分とするガソリンに分解するときは 
表 8 Rock Springs 炭の 2 段水素化分解生成ガ ソリン $\left(50 \sim 150^{\circ} \mathrm{C}\right)$ およびそのハイドロ フォーメートの組成

\begin{tabular}{|c|c|c|}
\hline & 重 & 量 \% \\
\hline & $\begin{array}{l}\text { 気相分解 } \\
\text { ガソリン }\end{array}$ & $\begin{array}{l}\text { ハイドロフ } \\
\text { ォーメート }\end{array}$ \\
\hline パラフィン & 19.3 & 16.0 \\
\hline ナフテン & 51.6 & 14.8 \\
\hline シクロペンタン & 0.3 & 0.3 \\
\hline メチルシクロペンタン & 8.7 & 6.2 \\
\hline シクロヘキサン & 3.6 & 0.8 \\
\hline ジメチルシクロペンタン & 7.1 & 3.7 \\
\hline メチルシクロヘキサン & 7.1 & 1.1 \\
\hline エチルシクロペンタン & 5.2 & 0.7 \\
\hline $\mathrm{C}_{8}$-ナフテン & 10.5 & 2.1 \\
\hline $\mathrm{C}_{9}$-ナフテン & 9.0 & - \\
\hline アロマチックス & 28.0 & 67.0 \\
\hline ベンゼン & 6.2 & 14.1 \\
\hline トルエン & 11.2 & 25.7 \\
\hline エチルベンゼン & 3.2 & 7.7 \\
\hline m-, p-キシレン & 6.2 & 15.6 \\
\hline 0-キシレン & 1.2 & 3.7 \\
\hline オレフィン & 1.1 & 2.2 \\
\hline
\end{tabular}

図14のよう飞無水無灰の原料炭 $1 \mathrm{t}$ 当り $1,280 \mathrm{Nm}^{3}$ といら多量の水素が必要となり, エネルギー効率が低 下する。著者は現在石油系重質油のハイドロクラッキ ングについて研究を行なっているが，かって経験した 石炭液化にくらべてはるか溶易であり, 水素消費量 も少ない。将来, 原油の輸入が制約されるような事態 が生じたときは現在輸入原油の約 $50 \%$ を占める重油 からガソリン〜軽油の留出油を製造し, 石炭は重油の 代替に用いることが望ましい。この場合重油の流通・ 消費機構に石炭をのせるため石炭の液化が 必要とな る。

したがって，これから開発すべき石炭直接液化技術 は可及的低い反応圧力, 水素消費で石炭をクリーンな 燃料油に変換する技術である。実用化の時期が1990年 以降とすると燃料油の硫黄分は $0.1 \%$ か，それ以下と することが必要とならう。硫黄分のきわめて少ないか つ炭の場合を除き，一般には 1 段の反応で石炭を硫黄 分 $0.1 \%$ 以下の燃料油に変換することは困難である。 石炭液化と最近進歩の著しい石油系燃料油の水素化精 製技術の組合せが必要となるものと考兄られる。この 場合には第 1 段の石炭液化プロセスの役割は石炭に重 油なみの流動性を与えると同時に水素化精製用 $\mathrm{Co}$ ・
Mo・アルミナ触媒を被毒する物質を除去することに なる。Consolidation Coal Co. のレポートによれ ば, 石炭の溶剤抽出物中にはフィルターされない微細 な無機物が含まれて扣り, 水素化処理触媒を被毒する といわれている。被毒物質を完全に除去するために は, 減圧蒸留または残油の溶剂脱孔きに類似した处理 が必要であり, 石炭はこれらの工程にかけられる程度 に分解しなければならない。ただし従来法のように石 炭を常圧留出油にまで分解する必要はないので, 水素 消費を低下させるために基本構造単位の分解はできる だけさけるべきであろう。

このよらな第 1 段の石炭液化に際して, 反応圧力を 低下させるための手段は図 $5 ， 6 ， 9$ 抢よび表 $2 ， 3$ に示したように原料炭, 触媒怙よび混合油のいずれ かまたはこれらを組合せた選択ということになる。 現在アメリカで開発の行なわれている H-Coal, Synthoil 両プロセスなどは石油精製の面で発展した触媒 を石炭液化へ直接応用しょうとする試みであり， Exxon Donor Solvent プロセスは混合油の改善をね らったものである。わが国とアメリカでは国情の違い から要請される石炭液化製品の性状に当然差があり, また石炭資源保有国に技術を提供するためにもわが国 独自の技術を開発することが必要である。本文が今後 のわが国に和ける石炭液化技術開発にいささかなりと も役立つところがあれば幸いである。

$$
\text { 文献 }
$$

1) M. G. Pelipetz et al., Bur. Mines, R. I., 4546 (1949)

2) S. Weller et al., Ind. Eng. Chem., 43, 1575 (1951)

3) S. Weller et al., Ind. Eng. Chem., 43, 1243 (1951)

4) S. Weller et al., Ind. Eng. Chem., 42, 330 (1950)

5) M. Orchin et al., Ind. Eng. Chem., 40, 1385 (1948)

6) I. B. Rapoport, "Chemistry and Jechnology of Synthetic Liquid Fuels”, p. 55, Israel Program for Scientific Translations, Jerusalem (1962)

7) C. H. Fischer et al., Ind. Eng. Chem., 29, 1371 (1937)

8) P. W. Sherwood, FIAT Final Rept., 952 (1947); PB 88, 839

9) C. C. Chaffee et al., Ind. Eng. Chem., 45, 822 
(1953)

10）坂部孜他，資源技術試験所報告，第61号（1965）

11) 坂部孜, 石油学会誌, 17, 848 (1974)

12) D. W. Van Krevelen, “Coal”, p.117, Elsevier Pub. Co., Amsterdam-London-New York-Princeton (1961)

13) P. W. Laughrey et al., Trans Am. Soc. Mech. Engrs., 72, 385 (1950)
14) E. E. Donath, "Chemistry of Coal Utilization", Suppl. Vol., Chap. 22, John Wiley \& Sons, New York (1963)

15）坂部孜他，資源技術試験所報告，第66号（1966）

16) L. L. Hirst et al., Bur. Mines, R. I., 4564 (1949)

17）坂部孜，資源技術試験所報告，第49号（1961）

\title{
Industrization and Studies on Direct Liquefaction of coal
}

\author{
by Tsutomu Sakabe
}

(National Research Institute for Pollution and Resources)

SYNOPSIS : - Industrial processes of coal liquefaction and studies on the direct liquefaction using powder catalysis are reviewed. Influences in the liquifaction on the reaction time, temperature, pressure, catalysis, pasting oils, and elementary components of coal are discussed from the results on the batch expreiments using autoclaves.

Relationship between the reaction conditions and elementary components of coal are explained. Heat and material balance, and the characteristics of the produced oil are also illustrated with regard to Begius-I. G. process. 